\title{
Photographic Credits
}

I. Bandi, Paris, plates 50 to 68

British Museum, London, plates 13, 14, 24

L. K. Carroll, Lagos, plate 20

W. Fagg, London, plates 16 to 19 and 21 to 23

Wilson Perkins Foss IV, Yale, plate 94

Institute of African Studies, University of Ghana, Legon, plate 97

Instituto Nacional de Antropología e Historia, Mexico City, plates

$33,41,42,44,46,49$

Mark Kinnaman, Yale, plate 86

W. Moore, Los Angeles, plate 25

Musée National des Arts Africains et Océaniens, Paris, plates 50 to 68

Museo Nacional de Antropología, Mexico City, plates 38 to 40,43 , $45,47,48$

Museum of Primitive Art, New York, plates 1 to 12

Alex Nicoloff, Berkeley, plate 79

Nigerian Museum, Lagos, plates 15, 87 
viii

Photographic Credits

Eugene R. Prince, Berkeley, plates 69 to 78

Rijksmuseum voor Volkenkunde, Leiden, plates 26 to 37

Robert H. Lowie Museum of Anthropology, Berkeley, plates 69 to 79

Roy Sieber, Bloomington, plate 96

Smithsonian Institution, Washington, D.C., plate 86

Robert F. Thompson, Yale, plates 80 to 85,87 to 93, and 95

Charles Uht, New York, plates 1 to 8 and 10 to 12

Raymond Wielgus, Chicago, plate 9 